\title{
ANURANS FROM IGUAZÚ NATIONAL PARK AND BUFFER AREA (ARGENTINA): REVIEW OF SPECIES LIST AND ECOLOGICAL NOTES ON THE LEAF-LITTER ASSEMBLAGES
}

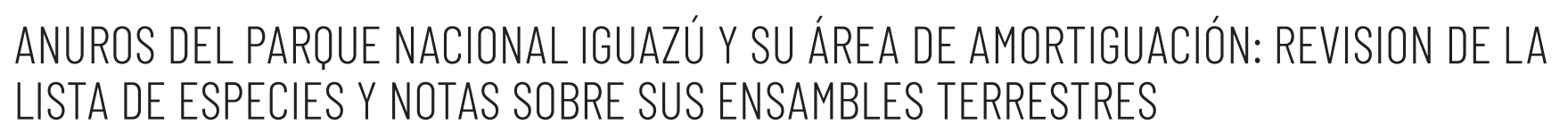

Carlos ARIEl López ${ }^{1^{*}}$ \& Michel VARajÃo GareY ${ }^{2}$

${ }^{1}$ Instituto Nacional de Medicina Tropical (INMeT) - ANLIS, Ministerio de Saludy Desarrollo Social de la Nación, Calle Ámbary Almafuerte s/n, Puerto Iguazú, Misiones, Argentina.

${ }^{2}$ Laboratório de Ecologia de Metacomunidades (LEMet), Universidade Federal da Integração Latino-Americana (UNILA), Foz do Iguaçu, Paraná, Brasil.

"Correspondence: lopez_arielc@yahoo.com.ar

Received: 2020-06-15. Accepted: 2021-03-10.

Resumen.- En este aporte actualizamos la lista de especies de anfibios del Parque Nacional Iguazú y su área de amortiguamiento, en el noreste de Argentina, y evaluamos de manera complementaria la distribución temporal de los anuros terrestres que habitan en el parque. Muestreamos mensualmente ocho cuerpos de agua, y ocho trampas con cercas de deriva entre abril de 2013 y febrero de 2016. Complementamos nuestros datos con datos publicados e inéditos sobre los anuros. Registramos 27 especies en nuestras muestras, en las que tres especies son nuevos registros para el Parque Nacional Iguazú y la zona de amortiguamiento: Ololygon aromothyella, Melanophryniscus devincenzii y Lithobates catesbeianus. Registramos diez especies en el conjunto de anuros de hojarasca, siendo Physalaemus cuvieri y Leptodactylus elenae las especies más frecuentes, que representan el 63\% de los individuos atrapados. A pesar de los cambios mensuales, la riqueza no varió estacionalmente, sin embargo, en los meses con las temperaturas más altas, encontramos una mayor riqueza de especies posiblemente relacionada a eventos estocásticos asociados a variables estacionales. Nuestros resultados confirman la importancia de la conservación del Parque Nacional Iguazú y de la provincia de mayor biodiversidad, Misiones, que alberga más del 50\% de las especies de anuros de Argentina.

Palabras clave.- Anfibios, clima, temperatura, variación temporal.

Abstract.- In this contribution we update the amphibian species list from Iguazú National Park and the buffer area, Misiones Province in northeastern Argentina, and we evaluate the temporal distribution of leaf-litter anurans that inhabit the park. We sampled monthly eight water bodies and eight pitfall traps with drift-fences between April 2013 and February 2016. We supplement our data with published and unpublished data. We recorded 27 species in our samples, of which, three species are new records for Iguazú National Park and the buffer area: Ololygon aromothyella, Melanophryniscus devincenzii and Lithobates catesbeianus. We recorded ten species in the leaf-litter anuran assemblage, Physalaemus cuvieri and Leptodactylus elenae being the most frequent species, representing $63 \%$ of the individuals trapped. Despite monthly climate changes, richness did not vary seasonally; however, we found a higher species richness in months with the most elevated temperatures possibly related to stochastic events interacting with seasonal variables. Our results confirm the conservation importance of Iguazú National Park and the most biodiverse province, Misiones, which houses more than $50 \%$ of the anuran species of Argentina.

Keywords.- Amphibians, climate, temperature, temporal variation. 


\section{INTRODUCTION}

Ecological communities are dynamic in space and time (Leibold \& Chase, 2018). In anuran assemblages, this dynamism is associated with the high species diversity and variety of life histories (Wells, 2007). Biotic and abiotic factors influence spatial and temporal variations in communities. In general, anuran assemblages change over time due to climatic conditions (e.g. Ryan et al., 2014; Ryan et al.,2015). Temporal variation seems be most influenced by temperature, and precipitation (Hartel et al., 2007; Garey \& Silva, 2010; Bolzan et al., 2019), but also by pressure from interspecific interactions (e.g. Toft, 1985) and environmental changes (Bonecker et al., 2013). However, this information is based mainly on samples in water bodies used by anurans for reproduction, and data on leaf-litter anuran assemblages are more scarce (e.g., Rocha et al., 2013), with a precedent for northeastern Argentina (region that we sampled in the present study) in the work of Gangenova et al. (2018), where they compared anuran assemblages from pine plantations with those of the native forest, but they did not assess the community's temporal variation.

The knowledge of species richness and composition of assemblages, their species' relative abundances, and the factors that drive assemblage structure in a natural protected area, constitute the first steps necessary to accomplish conservation goals (Scott, 2001; D'Amen et al., 2017), especially if the group shows conservation problems worldwide, as in amphibians (McCallum, 2007, Scheele et al., 2019). Recently declared the National Capital of Biodiversity, the province of Misiones is the most biodiverse in Argentina (Placci \& Di Bitetti, 2006). The Iguazú National Park (INP) in the north of Misiones Province protects Argentina's sector of Interior Atlantic Rain Forest or Paranaense Forest (Oyarzabal et al., 2018), a relictual landscape and a world hotspot of biodiversity (Myers et al., 2000; Holtz $\&$ Placci, 2003; Mettermeier et al., 2004). Despite being one of the most studied protected area in Argentina, the information about the amphibian community and its populations in the INP is fragmented and outdated. Montanelli \& Acosta (1991) provided the first inventory of the herpetofauna of the INP. Based on that document and unpublished technical reports - Bosso \& Céspedes, 1995; Gangenova \& Guzman, 2011, Apepú, 2013-, INP's latest Management Plan (SIB, 2017) recognizes 24 species of anurans inhabiting the INP.

Due to the extreme importance of the Iguazú National Park region for the conservation of the biodiversity, including amphibians, and the existing unconsolidated data on the anuran fauna, we now provide an update of the amphibian species list from INP and the surrounding buffer area. In addition, we report the patterns of temporal variation in species richness, and composition of leaf-litter anuran assemblages in the INP.

\section{MATERIALS AND METHODS}

\section{Study Site}

The Iguazú National Park $\left(25.690758^{\circ} \mathrm{S} ; 54.477886^{\circ} \mathrm{W}\right)$ is known worldwide for Iguazú Falls, which is one of the main tourist centers of the country. Associated with the Iguazú River, on the border with Brazil, the INP protects 67620 hectares of Atlantic Rain Forest, which is currently reduced to approximately $13 \%$ of its original extension and is the largest remaining forest of that landscape (Ribeiro et al., 2009). The INP is under the influence of a warm and humid subtropical climate, with an average annual rainfall of $2000 \mathrm{~mm}$, without a dry season. However, there is usually more rain in spring and late autumn. The average annual relative air humidity is $78.6 \%$. INP is located in the southwestern foothills of the Brazilian basaltic shield, and its relief is undulating with heights between $200-350 \mathrm{~m}$ asl. The streams' hydric regimes are quite variable, depending on rainfall. The average annual temperature is $20.7^{\circ} \mathrm{C}$, with an average maximum of $31.8^{\circ} \mathrm{C}$ and an average minimum of 10.7 ${ }^{\circ} \mathrm{C}$. The basalt exposed to temperature and humidity results in the characteristic red soil -altisols- of this region (SIB, 2017; Oyarzabal et al., 2018). The INP has the most diverse flora of Argentina with high structural complexity (Srur et al., 2009).

We sampled the anurans of the INP and in northwest and east regions of the buffer area. Cabure- $1\left(25.679786^{\circ} \mathrm{S} ; 54.141343^{\circ} \mathrm{W}\right)$ is a town in the eastern part of the INP buffer area. There the local community develops agricultural activities. In the northwest buffer area - known as "600 Hectareas" (25.615479 $\mathrm{S}$; $54.555806^{\circ}$ W) - the activity is mainly tourism.

For species surveys, not including leaf-litter assemblage surveys, we sampled the following sites within the INP: 1) La Cantera $\left(25.689045^{\circ} \mathrm{S} ; 54.475219^{\circ} \mathrm{W}\right)$, located at the entrance to the INP, is an old quarry, there is a rocky depression of 100 x 170 meters, sparsely vegetated, with floodable sectors. 2) The disturbed edges of the access route (DER) are vegetation strips between two and four meters wide, parallel to the access route, about five kilometers long. 3) The Old Airport (OA) $\left(25.767543^{\circ}\right.$ S; $54.452244^{\circ} \mathrm{W}$ ) an area of approximately four hectares; the environment floods, with abundant grasses and isolated trees. 4) The Apepú Detachment (Apepú) is located in the core area of the reserve. In the vicinity is an oval lagoon $\left(25.566335^{\circ} \mathrm{S} ; 54.295951^{\circ}\right.$ W) $80 \times 140$ meters, approximately 1.5 meters deep in the center, wholly covered with emerging grasses, with a variable regime. 


\section{Inventory and monitoring}

We applied different methods to obtain a more complete inventory of anurans, including primary and secondary data collection. For primary data, we use the visual encounter survey during night and day (Crump \& Scott, 1994), the acoustic survey of breeding sites (Scott \& Woodward, 1994), and passive sampling, specifically for the study of leaf-litter assemblies, using eight pitfalls traps with drift-fences (Corn, 1994). These traps were numbered from one to eight. We sampled eight environments associated with water bodies (pitfall traps numbered 1, 3, 5 and 8 - as part of the study of the leaf-litter community-, La Cantera, Apepú, Old Airport and INP roadsides). In these, eight sites sampling effort was between 1 to 9 hours/researcher per site. Servicing pitfall traps 1, 3, 5 and 8 required 5 hours/researcher, and sampling the La Cantera, Old Airport and INP roadsides 8 to 27 hours/researcher of total effort. In Apepú sampling effort was 59 hours/researcher at the site.

To sample leaf-litter anuran assemblages, we used eight pitfall traps with drift-fences (PT) (Table 1), each one with four buried plastic 80 -liter buckets joined together by plastic net drift fences $5 \frac{1}{2}$ meters long and $1 / 2$ meter tall (drift-fences) in a Y-shaped design (Corn, 1994), or a linear design where vegetation did not allow the Y-design. Despite the difference in shape of the pitfall traps due to local conditions, we assume that each trap, in Y-shaped or linear design, has the same capture probability. During the sampling period, the pitfall traps were checked daily in the morning or afternoon, totaling 504 days/trap or 12096 buckets/night between November 2013 and April 2015. PT were distributed in different landscape units of INP according to the surface drainage (fast drainage or flood-prone units), presence of a water body (lentic, lotic, or none) and vegetation type (native or exotic).
We used only visual encounter surveys in buffer areas. The samplings were carried out during the day and night. In the "600 Hectares" site, 13 daily and 12 nocturnal searches were made, which represented 52 hours/sampling. We sampled two water bodies, (i) a lagoon $\left(25.603518^{\circ} \mathrm{S} ; 54.548575^{\circ} \mathrm{W}\right)$, (ii) a flooded area in a low jungle environment $\left(25.600175^{\circ} \mathrm{S} ; 54.550586^{\circ} \mathrm{W}\right)$. In the western region, Cabure-1 $\left(25.680780^{\circ} \mathrm{S} ; 54.556854^{\circ} \mathrm{W}\right)$, we spent eight days and six nights of fieldwork totaling 48 hours/ researcher searching for anurans in six family-owned production facilities $\left(25.70608^{\circ} \mathrm{S} ; 54.1415^{\circ} \mathrm{W}-25.69912^{\circ} \mathrm{S}\right.$; $54.14017^{\circ} \mathrm{W}-25.67773^{\circ} \mathrm{S} ; 54.155513^{\circ} \mathrm{W}-25.67729^{\circ} \mathrm{S} ; 54.15141^{\circ} \mathrm{W}$ $-25.69129^{\circ} \mathrm{S} ; 54.15282^{\circ} \mathrm{W}$ and $25.85747^{\circ} \mathrm{S} ; 54.9754^{\circ} \mathrm{W}$ ). Outside of the protected area, there is an abrupt change in the landscape, with the soil mainly dedicated to agriculture and livestock, eliminating the native vegetation, and replacing it with pasture. In this area, we found small strips of native vegetation protecting the banks of countless streams, and there are artificial lagoons of various dimensions that serve as water reservoirs for human consumption and livestock, which we sampled in search of anurans.

For each anuran captured, we took three photographs dorsal, lateral, and ventral views - for the comparison of designs, coloring, and gland distribution (Hagström, 1973; Doody, 1995; Pereira \& Maneyro, 2016). After data collection, the individuals were released no less than 10 meters from the pitfall trap. Since the collection of individuals was not allowed, the determination of the species trapped was made in the field or in the laboratory by analyzing the photographs of the individuals and the bibliography (keys, original descriptions, field guides). Weather data was provided by the National Weather Service (https:// www.smn.gob.ar/). We obtained three climatic variables: monthly mean temperature, precipitation and air moisture.

Tabla 1. Principales variables y posición de las trampas de caída utilizadas para el estudio de los ensambles de anuros de hojarasca en el Parque Nacional Iguazú.

Table 1. Main variables and position of the pitfall-traps used for the study of leaf-litter assemblages in the Iguazú National Park.

\begin{tabular}{ccccccccc}
\hline Variable & PT1 & PT2 & PT3 & PT4 & PT5 & PT6 & PT7 & PT8 \\
\hline Drainage & low & high & low & high & low & high & high & low \\
Vegetation & native & native & native & native & native & exotic & native & exotic \\
Water body & lentic & none & lentic & none & lentic & lotic & none & lentic \\
Latitude & $25^{\circ} 40.6^{\prime}$ & $25^{\circ} 40.4^{\prime}$ & $25^{\circ} 40.4^{\prime}$ & $25^{\circ} 39.2^{\prime}$ & $25^{\circ} 39.4^{\prime}$ & $25^{\circ} 41.4^{\prime}$ & $25^{\circ} 40.9^{\prime}$ & $25^{\circ} 41.1^{\prime}$ \\
Longitude & $54^{\circ} 26.9^{\prime}$ & $54^{\circ} 26.9^{\prime}$ & $54^{\circ} 26.9^{\prime}$ & $54^{\circ} 27.6^{\prime}$ & $54^{\circ} 27.6^{\prime}$ & $54^{\circ} 27.5^{\prime}$ & $54^{\circ} 27.7^{\prime}$ & $54^{\circ} 28.2^{\prime}$ \\
\hline
\end{tabular}


We obtained secondary data by searching for published articles using Google Scholar platform applying the terms "Iguazú National Park", "Amphibians" and "anurans" in both Spanish and English. Also, we search for technical reports of National Parks Administration staff to consolidate an amphibian species list from INP.

\section{Statistical processing}

To assess sampling efficiency of the leaf-litter anurans survey, we used sample-based rarefaction curves by randomizing the samples 1,000 times (Gotelli \& Colwell, 2001) using Past 3.0 software (Hammer et al., 2001). We applied Circular Statistical analysis to assess whether there was seasonality in leaf-litter anuran capture using software Oriana 2.02 (Kovach, 2004). To evaluate which climate variables (i.e. mean temperature, precipitation and air moisture) explain the temporal variation of anuran richness, we used Generalized Linear Models (GLM) analysis using quasi-Poisson distribution due to data overdispersion. We standardize climate variables using the Z-score transformation. These analyzes were implemented in the R software (R Development Core Team, 2019).

\section{RESULTS}

Anuran species list.- We recorded 32 species of anurans based on primary and secondary data from the INP and surrounding buffer areas. The anurans belonged to 14 genera, in seven families: Hylidae (six genera, 15 species), Leptodactylidae (two genera, eight species), Bufonidae (two genera, four species), Odontophrynidae (two genera, two species), and Alsodidae, Centrolenidae and Ranidae with one species each (Table 2, Figs. 1 and 2). We recorded 27 species from our sampling efforts, including three species that had not been found before in this area. The secondary data provided five species that we did not record.

Leaf-litter anuran assemblage. In the eight PT we recorded 373 individuals from ten species, only two recaptures. According to the rarefaction curve, we found that the sampling was representative of the leaf-litter anuran assemblage (Fig. 3). The most frequent species were Physalaemus cuvieri Fitzinger, 1826 ( $\mathrm{n}=128,34 \%$ of the individuals) and Leptodactylus elenae Heyer, 1978 ( $n=111,29 \%$ of the individuals) represented $63 \%$ of the sampling the other abundant species recorded were Rhinella ornata (Spix, 1824) ( $\mathrm{n}=54)$, Leptodactylus mystacinus (Burmeister, 1861) $(\mathrm{n}=28)$, Proceratophrys avelinoi Mercadal de Barrio and Barrio, 1993 ( $\mathrm{n}=22)$ and Elachistocleis bicolor (Guérin-Méneville, 1838) $(\mathrm{n}=19)$. P. cuvieri, L. elenae, P. avelinoi and L. mystacinus were recorded in most of the PT, with records in $90 \%$ of the PT for the first two species and $60 \%$ of the PT for the last two. The PT captured between $20-80 \%$ of the total leaf litter species recorded in the study, species trapped ranges from $\mathrm{PT} 1$ (eight species, $\mathrm{n}=$ 81) to $\mathrm{PT} 7$ (two species, $\mathrm{n}=5$ ) (Table 2).

Although the highest species richness was recorded in the hottest and wettest period, the temporal variation did not show a well-marked seasonal pattern (Rayleigh Test $\mathrm{Z}=0.585 ; \mathrm{P}=0.56$ ); September was the month with the highest number of registered species (six species), while May was the month with the lower number of recorded species (1 species) (Fig. 4). Moreover, the absence of seasonality, temporal variation in species richness was marginally positively associated with temperature, in months with a higher temperature, higher species richness was recorded (Table 3, Fig. 5).

\section{DISCUSSION}

The current number of 32 anuran species of Iguazú National Park and surrounding buffer area is remarkable and represents approximately $52 \%$ of the species of anurans from Misiones Province, and $18 \%$ of the anurans from Argentina (Vaira et al., 2012; Cardoso \& Pereyra, 2018, Baldo et al., 2019). Research in other protected areas of Misiones reported 15 species of anurans 8 km apart from INP (López \& Kubisch, 2008), 21 species $110 \mathrm{~km}$ apart from INP (López \& Nazer, 2009), 20 species $45 \mathrm{~km}$ apart from INP (Lescano et al., 2013) and recently Gangenova et al., (2018) reported 18 species in the native forest of the INP and the Urugua-í Provincial Park -adjacent to INP. Our results confirm the importance of the INP in the conservation of the anurans.

Our species list resolved some differences among previous anurans species list of INP (Montanelli \& Acosta (1991) and unpublished technical reports). Our results added two native species to the INP (Ololygon aromothyella and Melanophryniscus devincenzi); besides, we verified the presence of 16 species in the surrounding buffer area, one of which is an exotic invasive: Lithobates catesbeianus (Lowe et al., 2000; Daszak et al., 2003). Ololygon aromothyella is distributed, according to the original description, only in the center of the province of Misiones, in two localities in Uruguay, two localities in Brazil, and it is probably present in Paraguay (Frost, 2020). Our record is the northernmost for the $O$. aromothyella in Argentina. One of the authors (CAL) obtained records of the species in the margins of National Route $19\left(25,856274^{\circ} \mathrm{S} ; 54,167898^{\circ} \mathrm{W}\right)$ within the Urugua-í Provincial Park (unpublished data). O. aromothyella has been categorized as Not Threatened for Argentina (Vaira et al., 2012), while at the global level, it is classified as Data Deficient (Stuart, 2006). Melanophryniscus devincenzii is distributed in 
Tabla 2. Especies de anfibios registrados en las trampas de caída (PT) y en la revisión de la literatura en el Parque Nacional Iguazú. Fuentes: a= Montanelli \& Acosta, 1991, b= Bosso \& Céspedes, 1994, c= Gangenova \& Guzmán, 2011, d= Apepú, 2013, e= López \& Grassi, 2019, D= bordes perturbados de las vías de acceso, 0= antiguo aeropuerto, A= Apepú, Ct= Cantera, ${ }^{*}=$ área de amortiguamiento, $X=$ fuera de las trampas de caída.

Table 2. Amphibian species registered in the Iguazú National Park in pitfall-traps (PT) and the literature review. Sources: a = Montanelli \& Acosta, 1991, b= Bosso \& Céspedes, 1994, c= Gangenova \& Guzmán, 2011, d= Apepú, 2013, e= López \& Grassi, 2019, D= disturbed edges of access roads, $0=$ old airport, A= Apepú, Ct= Cantera, * Buffer area, X= outside the pitfall-traps.

\begin{tabular}{|c|c|c|c|c|c|c|c|c|c|c|}
\hline Species & PT1 & PT2 & PT3 & PT4 & PT5 & PT6 & PT7 & PT8 & Site & Reference \\
\hline \multicolumn{11}{|l|}{ Bufonidae } \\
\hline Melanophryniscus devincenzii Klappenbach, 1968 & & & & & & 2 & & & 0,0 & Present study \\
\hline Rhinella ornata (Spix, 1824) & 15 & 10 & 10 & 5 & 9 & 5 & & & & $a, b$, Present study \\
\hline Rhinella diptycha (Cope, 1862) & & & & & & & & & $A, D, 0, *$ & $a, b, d$, Present study \\
\hline Rhinella icterica (Spix, 1824) & & & & & & & & & $*$ & Present study \\
\hline \multicolumn{11}{|l|}{ Hylidae } \\
\hline Boana albopunctata (Spix, 1824) & & & & & & & & & $\mathrm{A}, \mathrm{Ct}$ & $a, b, c$, Present study \\
\hline Boana caingua (Carrizo, 1991) & & & & & & & & & Ct & b, c, Present study \\
\hline Boana faber (Wied-Neuwied, 1821) & & & & & $x$ & & & & $\mathrm{Ct}, *$ & $a, b, c$, Present study \\
\hline Boana raniceps (Cope, 1862) & & & & & & & & & $0,0, *$ & c, Present study \\
\hline Dendropsophus minutus (Peters, 1872) & & & & & $x$ & & & & $A_{1}^{*}$ & $a, b, c, d$, Present study \\
\hline Dendropsophus nanus (Boulenger, 1889) & & & & & $x$ & & & & $A_{1}^{*}$ & $a, b, c, d$, Present study \\
\hline Dendropsophus sanborni (Schmidt, 1944) & & & & & & & & & $0,0, *$ & c, Present study \\
\hline Itapotihyla langsdorffii (Duméril and Bibron, 1841) & $x$ & & $x$ & & & & & & $\mathrm{~A}, \mathrm{Ct}, \mathrm{D}, \mathrm{O}$ & $a, c, d$, Present study \\
\hline Scinax fuscovarius (Lutz, 1925) & & & & & & & & & $A, D, 0, *$ & $a, b, c$, Present study \\
\hline Scinax nasicus (Cope, 1862) & & & & & & & & & $*$ & c, Present study \\
\hline Scinax perereca Pombal, Haddad, and Kasahara, 1995 & & & & & & & & & & C \\
\hline Scinax squalirostris (Lutz, 1925) & & & & & & & & & & $a, b, c$ \\
\hline Ololygon aromothyella (Faivovich, 2005) & & & & & $x$ & & & & & Present study \\
\hline Ololygon berthae (Barrio, 1962) & & & & & & & & & A & $d$ \\
\hline Trachycephalus typhonius (Linnaeus, 1758) & & & & & & $x$ & & & A & $a, b, c$, Present study \\
\hline \multicolumn{11}{|l|}{ Microhylidae } \\
\hline Elachistocleis bicolor (Guérin-Méneville, 1838) & 11 & 2 & 2 & & & 1 & & 3 & $*$ & b, c, Present study \\
\hline \multicolumn{11}{|l|}{ Leptodactylidae } \\
\hline Leptodactylus elenae Heyer, 1978 & 19 & 17 & 36 & 7 & 18 & 7 & 4 & 3 & A, Ct & a, c, Present study \\
\hline Leptodactylus fuscus (Schneider, 1799) & & & & & & & & & $A, D, 0, *$ & $a, b, c, d$, Present study \\
\hline Leptodactylus luctator (Steffen, 1815) & 1 & & & 3 & 1 & & & & $A_{1}^{*}$ & $a, b, c$, Present study \\
\hline Leptodactylus podicipinus (Cope, 1862) & & & & & & & & & A & a, Present study \\
\hline Leptodactylus mystacinus (Burmeister, 1861) & 2 & 4 & 9 & 2 & 7 & 3 & & 1 & & $a, b, c$, Present study \\
\hline Physalaemus gracilis (Boulenger, 1883) & & & & & 1 & & & & $*$ & a, Present study \\
\hline Physalaemus cuvieri Fitzinger, 1826 & 28 & 27 & 38 & 6 & 7 & 13 & 1 & 8 & $\mathrm{~A}, \mathrm{Ct}_{1} *$ & $a, b, c, d$, Present study \\
\hline
\end{tabular}


Tabla 2 (cont.). Especies de anfibios registrados en las trampas de caída (PT) y en la revisión de la literatura en el Parque Nacional Iguazú. Fuentes: a= Montanelli \& Acosta, 1991, b= Bosso \& Céspedes, 1994, C= Gangenova \& Guzmán, 2011, d= Apepú, 2013, e= López \& Grassi, 2019, D= bordes perturbados de las vías de acceso, 0= antiguo aeropuerto, A= Apepú, Ct= Cantera, ${ }^{*}=$ área de amortiguamiento, $X=$ fuera de las trampas de caída.

Table 2 (cont.). Amphibian species registered in the Iguazú National Park in pitfall-traps (PT) and the literature review. Sources: a = Montanelli \& Acosta, 1991, b= Bosso \& Céspedes, 1994, c= Gangenova \& Guzmán, 2011, d= Apepú, 2013, e= López \& Grassi, 2019, D= disturbed edges of access roads, $0=$ old airport, A= Apepú, Ct= Cantera, * Buffer area, X= outside the pitfall-traps.

\begin{tabular}{|c|c|c|c|c|c|c|c|c|c|c|}
\hline Species & PT1 & PT2 & PT3 & PT4 & PT5 & PT6 & PT7 & PT8 & Site & Reference \\
\hline \multicolumn{11}{|l|}{ Odontophrynidae } \\
\hline Odontophrynus americanus (Duméril and Bibron, 1841) & 2 & & & & & & & 1 & $*$ & $a, b$, Present study \\
\hline Proceratophrys avelinoi Mercadal de Barrio and Barrio, 1993 & 3 & 2 & 3 & 1 & 1 & 10 & & 2 & & a, c, Present study \\
\hline \multicolumn{11}{|l|}{ Alsodidae } \\
\hline Limnomedusa macroglossa (Duméril and Bibron, 1841) & & & & & & & & & & $b$ \\
\hline \multicolumn{11}{|l|}{ Centrolenidae } \\
\hline Vitreorana uranoscopa (Müller, 1924) & & & & & & & & & & a \\
\hline \multicolumn{11}{|l|}{ Ranidae } \\
\hline Lithobates catesbeianus (Shaw, 1802) & & & & & & & & & $*$ & $\mathrm{e}$ \\
\hline
\end{tabular}

the southern (AmphibiaWeb, 2020) and the central areas of Misiones (López \& Nazer, 2009), and in Corrientes Province of Argentina, with a few records in southern Brazil, Paraguay, and Uruguay (Frost, 2020). Although at the country level it is categorized as Not Threatened, at the global level it is listed as Endangered (Stuart, 2006). Two species previously listed for INP are not included in our species list. The species Scinax $x$-signatus reported by Montanelli \& Acosta (1991) is not included in the list of amphibians in the INP, as it does not inhabit the country (AmphibiaWeb, 2019; Vaira et al., 2012). Dermatonotus muelleri is not included either, as the species should not be present in the province of Misiones (Vaira et al., 2012), and there are no vouchers in the Center for Subtropical Ecological Research (CIES) collection. Individuals assigned to Odontophrynus americanus require future studies, given the recent description of O. reigi distributed in the study area (Rosset et al., 2021).

We recorded the presence of an exotic species, Lithobates catesbeianus, in the surrounding area of INP. L. catesbeianus has already been recorded in other areas in Argentina (see López \& Grassi, 2019); nonetheless, this is the first record of the species near the INP. L. catesbeianus can cause a reduction in anuran biodiversity in the sites it colonizes (Silva et al., 2011; Leivas et al., 2013; Laufer \& Gobel, 2017). Moreover, this species was associated with Batrachochytrium dendrobatidis transmission (Daszak et al., 2003), a disease often lethal to anurans. In addition to this complex situation, the invasion by L. catesbeianus in the northeast of Misiones might be exacerbated by an invasive wave that comes from southern Brazil, which seems to have already occurred in different areas at the east of the province of Misiones (Both et al., 2011).

We observed the absence of a well-marked seasonality in anurans richness, although not seasonal, temporal changes in species richness was positively associated with temperature variation. The positive relationship between richness and temperature has already been observed in other anuran assemblages in different biomes (e.g. Conte \& Rossa-Feres, 2006; Garey \& Silva, 2010; Bolzan et al., 2019). Anurans are ectothermic (Wells, 2007), so it is expected that higher the temperature

Tabla 3. Resultado del Modelo Lineal Generalizado para las variaciones temporales de la diversidad específica de anuros del Parque Nacional Iguazú, Argentina.

Table 3. Results of Generalized Linear Model for temporal changes in anuran species richness in the Iguazú National Park, Argentina.

\begin{tabular}{ccccc}
\hline & $\begin{array}{c}\text { Coefficient } \\
\text { estimate }\end{array}$ & Std. Error & t value & P \\
\hline Intercept & 1.20 & 0.122 & 9.80 & 3.61 -08 \\
Temperature & 0.29 & 0.15 & 1.98 & 0.065 \\
Precipitation & 0.08 & 0.17 & 0.48 & 0.64 \\
Air Moisture & -0.04 & 0.17 & -0.23 & 0.82 \\
\hline
\end{tabular}



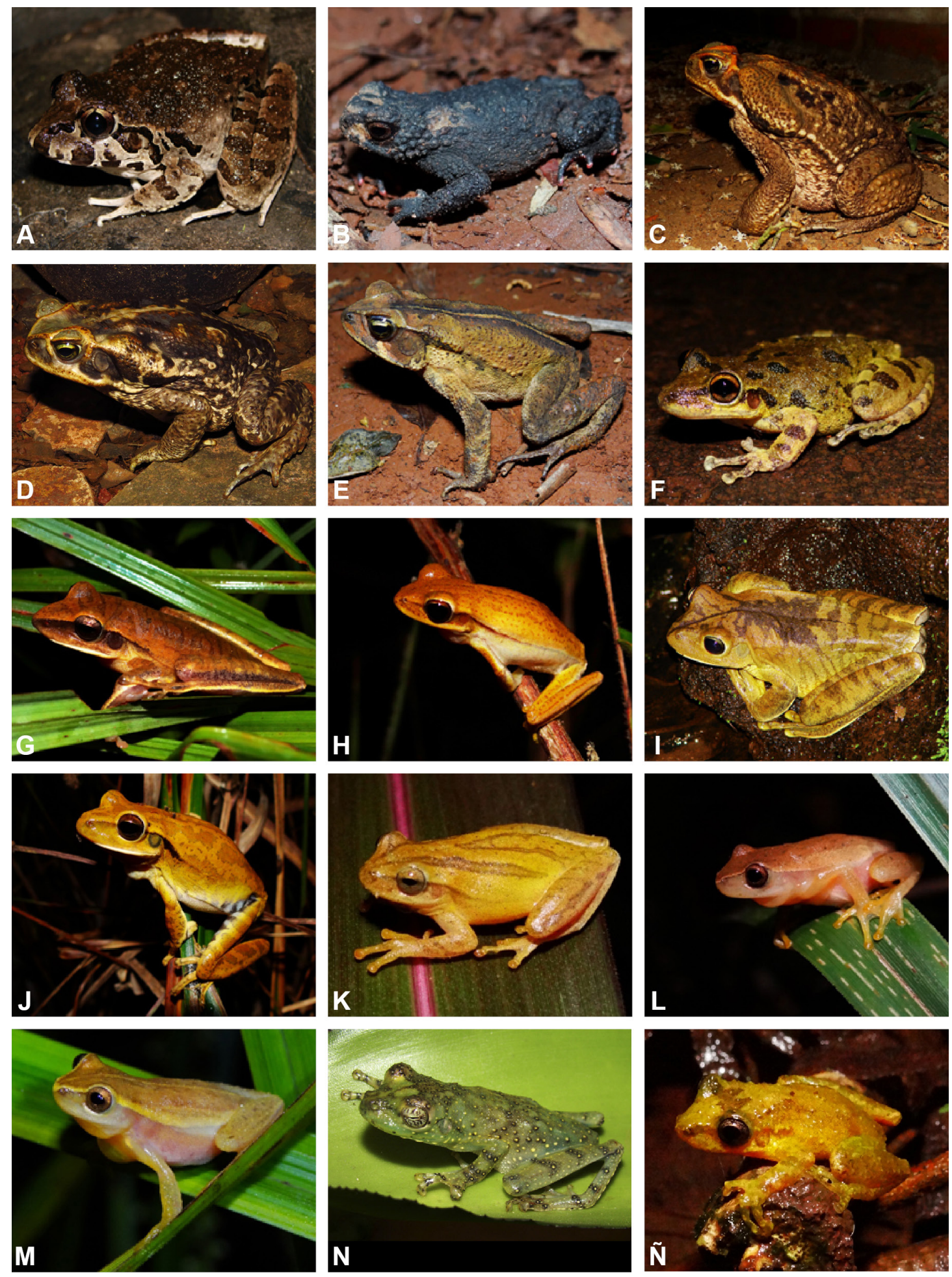

Figura 1. Algunos anuros del Parque Nacional de Iguazú, Argentina. A) Limnomedusa macroglossa; B) Melanophryniscus devincenzii; C) Rhinella dypticha; D) Rhinella icterica; E) Rhinella ornata; F) Scinax fuscovarius; G) Boana albopunctata; H) Boana caingua; I) Boana faber; J) Boana raniceps; K) Dendropsophus minutus; L) Dendropsophus nanus; M) Dendropsophus sanborni; N) Itapotihyla langsdorfii; Ñ) Ololygon aromothyella. Fotos: CAL.

Figure 1. Some anurans from Iguazú National Park, Argentina. A) Limnomedusa macroglossa; B) Melanophryniscus devincenzii; C) Rhinella dypticha; D) Rhinella icterica; E) Rhinella ornata; F) Scinax fuscovarius; G) Boana albopunctata; H) Boana caingua; I) Boana faber; J) Boana raniceps; K) Dendropsophus minutus; L) Dendropsophus nanus; M) Dendropsophus sanborni; N) Itapotihyla langsdorfii; Ñ) Ololygon aromothyella. Photos: CAL. 

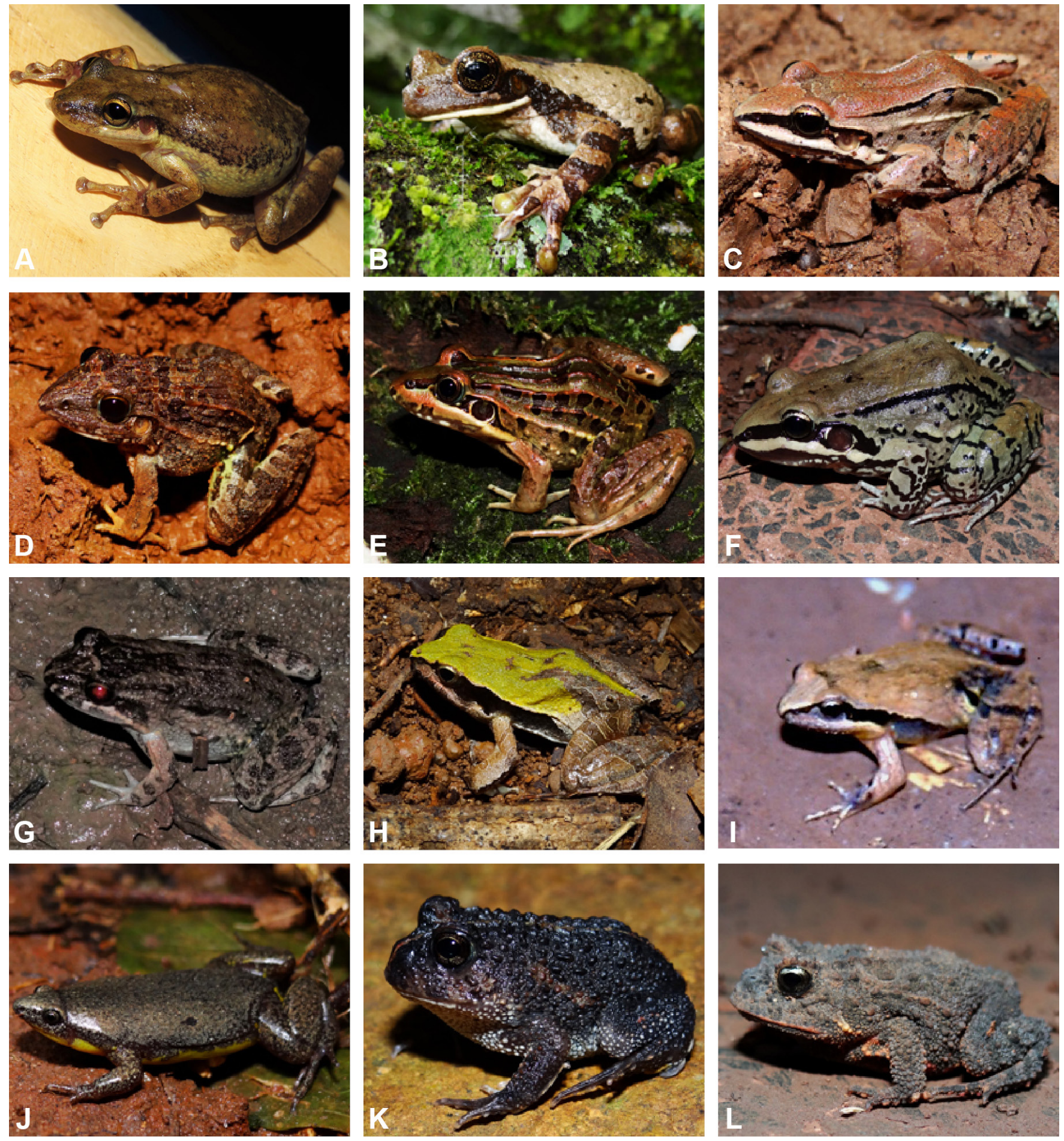

Figura 2. Algunos anuros del Parque Nacional de Iguazú, Argentina. A) Scinax nasicus; B) Trachycephalus typhonius; C) Leptodactylus elenae; D) Leptodactylus fuscus; E) Leptodactylus luctator; F) Leptodactylus mystacinus; G) Leptodactylus podicipinus; H) Physalaemus cuvieri; I) Physalaemus gracilis; J) Elachistocleis bicolor; K) Odontophrynus americanus; L) Procetophrys avelinoi. Fotos: CAL.

Figure 2. Some anurans from Iguazú National Park, Argentina. A) Scinax nasicus; B) Trachycephalus typhonius; C) Leptodactylus elenae; D) Leptodactylus fuscus; E) Leptodactylus (uctator; F) Leptodactylus mystacinus; G) Leptodactylus podicipinus; H) Physalaemus cuvieri; I) Physalaemus gracilis; J) Elachistocleis bicolor; K) Odontophrynus americanus; L) Procetophrys avelinoi. Photos: CAL. 


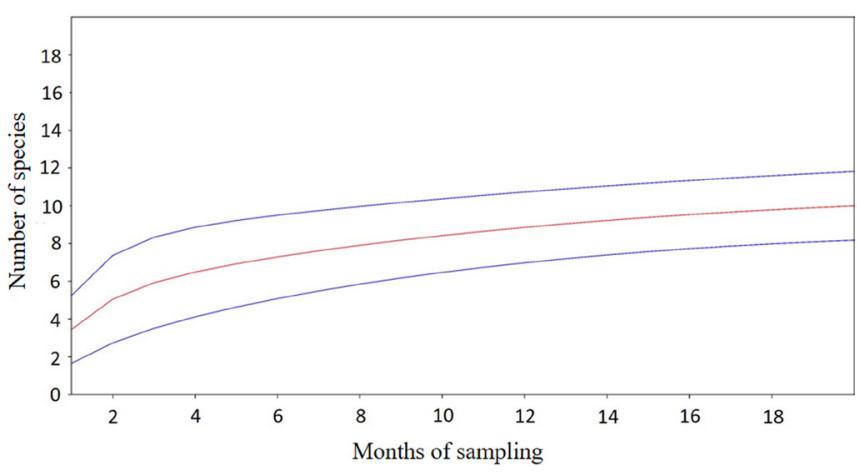

Figura 3. Curva de rarefacción de especies -línea roja- después de 1.000 muestreos aleatorios, los límites de los intervalos de confianza - línea azul - con un 95\% de confianza para los anuros de hojarasca del Parque Nacional Iguazú, Argentina.

Figure 3. Rarefaction curve of species richness-red line- after 1,000 random samples, the limits of the confidence intervals -blue line- are shown with 95\% confidence for the leaflitter anurans at the Iguazú National Park, Argentina.

there is an increase in the anuran activity, resulting in a higher probability of capture, especially in areas with seasonal climate (e.g. northeastern Argentina). We verified that some months of the hot-wet season held the highest species richness. However, this variation indicates a random pattern due to the absence of seasonal variation in species richness between the two seasons, hot-wet and cold-dry. The absence of a seasonal pattern is due to unexpected anuran activity in the winter. It may be associated

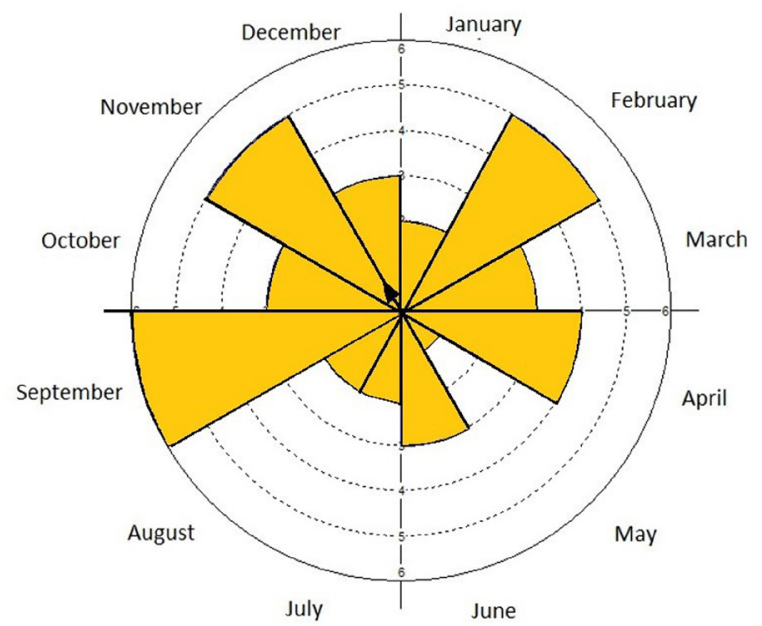

Figura 4. Diagrama circular que muestra la riqueza específica en el Parque Nacional Iguazú, Argentina. Las diferencias en la riqueza específica no es estadísticamente significativa $(P=0.56)$.

Figure 4. Circular diagram showing the species richness in the Iguazú National Park, Argentina. Differences in specific richness is not statistically significant ( $P=0.56)$.

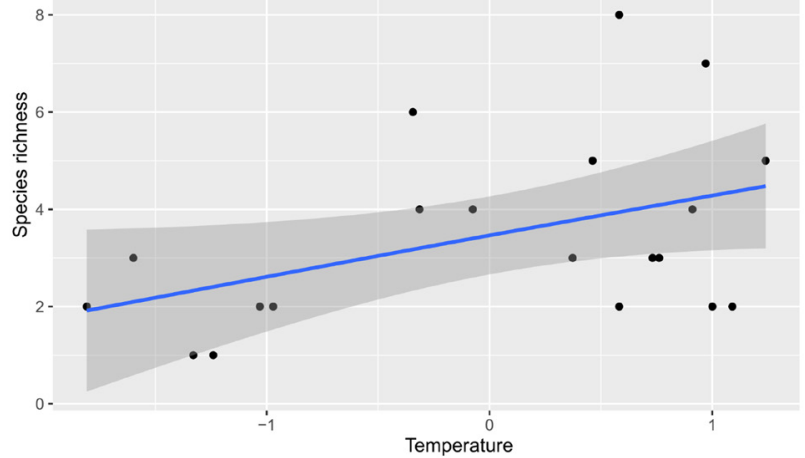

Figura 5. Respuesta temporal de la riqueza específica de anuros a la temperature media (transforma por los vaores-z) en el Parque Nacional Iguazú. El área gris representa al intervalo con $95 \%$ de confianza

Figure 5. Temporal response of anuran species richness to mean temperature (transformed by z-score) in the Iguazú National Park, Argentina. Dark grey area represent $95 \%$ confidence interval.

with the weather during sampling events, where days of winter temperatures close to summer highs were associated with increased anuran activity, although in the last 20 years the average annual temperature of the province of Misiones was higher than the normal climatological reference value (https://www.smn. gob.ar/clima/anomalia), constituting more of a climatological trend than a climatological event. We concluded that the activity of the INP anuran assemblages throughout the study period would be temperature driven. However, the response of the anuran assemblage could be related to a stochastic combination of climatic variables and by the strongly seasonal presence of certain resources and conditions (e.g. photoperiod).

\section{CONCLUSIONS}

Our anuran species list is crucial because it unifies information that was fragmented in several sources and is essential for the elaboration of management and conservation plans in protected areas and their vicinity. Furthermore, we encourage studies with anurans in the areas near to the park where additional species are expected and for monitoring L. catesbeianus population. Despite Misiones being home to the highest anuran species richness in Argentina (Lopez \& Prado, 2012; Vaira et al., 2012), there are still many areas that have not been inventoried, and we believe that many species have not yet been recorded. Finally, the application of basic biosecurity protocols during field work is suggested.

Acknowledgements.- MVG received a research grant from CNPq (422537/2016-0) and UNILA (edital PRPPG 80/2019 and PRPPG 110/2018). CAL would like to thank the CIES staff and the park 
rangers for their collaboration, INMeT for financial support, Quenia de los Santos for image edition and Norman Scott for comments and correction of the English version of the manuscript. Permission number 335/13 APN. We are grateful to ME Peichoto, holder of the research permit.

\section{CITED LITERATURE}

AmphibiaWeb. 2020. <http://amphibiaweb.org> University of California, Berkeley, CA, USA. [Accessed $27 \mathrm{Feb} 2020$ ].

Apepú, 2013. Campaña de Verano, Informe elaborado por Dirección Regional NEA, Administración de Parques Nacionales.

Baldo D., K. Araujo-Vieira, D. Cardozo, C Borteiro, F. Leal, M.O. Pereyra, F. Kolenc, M.L. Lyra, P.C.A. Garcia, C.F.B. Haddad \& J. Faivovich. 2019. A review of the elusive bicolored iris Snouted Treefrogs (Anura: Hylidae: Scinax uruguayus group). PLoS One 14:e0222131.

Bonecker, C.C., N.R. Simões, C.V. Minte-Vera, F.A. Lansac-Tôha, L.F.M. Velho \& A.A. Agostinho. 2013. Temporal changes in zooplankton species diversity in response to environmental changes in an alluvial valley. Limnologica 43:114-121.

Bolzan, A.M.R., M.V. Garey, P. A. Hartmann \& M.T. Hartmann. 2019. Too cold for dating: Temporal distribution of the calling activity of an austral anuran assemblage Herpetology Notes 12:961-968.

Bosso, A. y J. Céspedes. 1995. Listas actualizadas de los anfibios de las Áreas Protegidas Nacionales del nordeste argentino (Provincias de Misiones, Corrientes y Chaco). XI Reunión de Comunicaciones Herpetológicas. San Miguel de Tucumán 11-13 October 1995.

Both, C., R. Lingnau, A. Santos-Jr., B. Madalozzo, L. Pedrosa Lima \& T. Grant. 2011. Widespread occurrence of the American Bullfrog, Lithobates catesbeianus (SHAW, 1802) (ANURA: RANIDAE), in Brazil. South American Journal of Herpetology 6:127-134.

Cardoso, D.E. \& M.O. Pereyra. 2018. A new species of Physalaemus (Anura, Leptodactylidae) for the Atlantic Forest of Misiones, northeastern Argentina. Zootaxa 4387:580-590.

Conte, C.E. \& D.D.C. Rossa-Feres. 2006. Diversidade e ocorrência temporal da anurofauna (Amphibia, Anura) em São José dos Pinhais, Paraná, Brasil. Revista Brasileira de Zoologia 23:162-175.
Corn, P.S. 1994. Straight-line drift fences and pit fall traps. Pp. 108117. In: W.R. Heyer, M.A. Donnelly, W. McDiarmid, L.C. Hayek $\&$ M.S. Foster. Measuring and monitoring biological diversity. Standard methods for amphibians. Smithsonian Institution Press, Washington, DC.

Crump, M.L. \& N.J. Scott. 1994. Visual encounter surveys. Pp. 8492. In: W.R. Heyer, M.A. Donnelly, W. McDiarmid, L.C. Hayek $\&$ M.S. Foster. Measuring and monitoring biological diversity. Standard methods for amphibians. Smithsonian Institution Press, Washington, DC.

D'Amen, M., C. Rahbek, N.E. Zimmermann \& A. Guisan. 2017. Spatial predictions at the community level: from current approaches to future frameworks. Biological Review 92:169-187.

Daszak, P., A.A. Cunningham \& A.D. Hyatt. 2003. Infectious disease and amphibian population declines. Diversity and. Distributions 9:141-150.

Doody, J.S. 1995. A Photographic mark-recapture method for patterned amphibians. Herpetological Review 26:19-21.

Frost, D.R. 2020. Amphibian Species of the World: An Online Reference. Version 6.0. Electronic Database accessible at http://research.amnh.org/herpetology/am[hibia/index.html. American Museum of Natural History, New York, USA. [Accessed Jun 2020].

Gangenova E. y A. Guzmán. 2011. Informe de Avance Inventario de anfibios anuros del Parque Nacional Iguazú (Provincia de Misiones, Argentina) (Informe Técnico). Administración de Parques Nacionales.

Gangenova, E., G.A. Zurita \& F. Marangoni. 2018. Changes to anuran diversity following forest replacement by tree plantations in the southern Atlantic forest of Argentina. Forest Ecology and Management 424:529-535.

Garey, M.V. \& V.X. Da Silva. 2010. Spatial and temporal distribution of anurans in an agricultural landscape in the Atlantic Semideciduous Forest of southeastern Brazil. South American Journal of Herpetology 5:64-73.

Gotelli, N.J. \& R.K. Colwell. 2001. Quantifying biodiversity: procedures and pitfalls in the measurement and comparison of species richness. Ecology Letters 4:379-391. 
Hagström, T. 1973. Identification of newt species (Urodela, Triturus) by recording the belly pattern and a description of photographic equipment for such registration. British Journal of Herpetology, 4(I2):321-326.

Hammer, Ø., D.A.T. Harper \& P.D. Ryan. 2001. PAST: paleontological statistics software package for education and data analysis. Palaeontologia electronica 4:9.

Hartel, T., I. Sas, A. Pernetta \& I.C. Geltsch. 2007. The reproductive dynamics of temperate amphibians: a review. North-Western Journal of Zoology 3:127-145.

Holtz, S. \& G. Placci. 2003. Socioeconomic roots of biodiversity loss in Misiones. Chapter 19. Pp 207-226. In: Galindo, C., C. Leal \& I. Gusmào Câmara (Eds.). The Atlantic Forest of South América: Biodiversity Status, Threats, and Outlook. Island Press. Washington.

Kovach, W.L. 2004. Oriana for Windows, version 2.02. Pentraeth, Wales, UK: Kovach Computer Services.

Laufer, G. \& N. Gobel. 2017. Habitat degradation and biological invasions as a cause of amphibian richness loss: a case report in Aceguá, Cerro Largo, Uruguay. Phyllomedusa 16:289-293.

Leibold, M.A. \& J.M. Chase. 2018. Metapopulation Ecology. Monographs in Population Biology, vol. 59. Princeton University Press.

Leivas, P.T., M. Savaris, S. Lampert \& E.M. Lucas. 2013. Predation of Odontophrynus americanus (Anura: Odontophrynidae) by the invasive species Lithobates catesbeianus (Anura: Ranidae) in an Araucaria Forest remnant in southern Brazil. Herpetology Notes, 6:603-606.

Lescano, J.N., M.F. Bonino \& M.S. Akmentis. 2013. Composición y riqueza de anfibios y sus relaciones con las características de los sitios de reproducción en un sector de la Selva Atlántica de Misiones, Argentina. Cuadernos de Herpetología 27:35-46.

López,C.A. \& E. Grassi. 2019. Presencia de poblaciones naturalizadas de rana toro (Rana catesbeiana) en la zona de amortiguamiento oriental del Parque Nacional Iguazú, Argentina. Boletin de la Sociedad Zoologica del Uruguay (2 ${ }^{a}$ época) 28:87-91.

López, C.A. \& E. Kubisch. 2008. Relevamiento in situ de la herpetofauna del Refugio Privado de Vida Silvestre Yacutinga,
Provincia de Misiones (Argentina). APRONA Boletín Científico, 40:1-12.

López, C.A. \& J. Nazer. 2009. Relevamiento in situ de la herpetofauna de la Reserva y Refugio Privado Yaguaroundí, provincia de Misiones, Argentina. Boletín de la Sociedad Zoológica del Uruguay (Segunda época) 18:12-34.

López, C.A. \& W. Prado. 2012. Anfibios y reptiles de Misiones: guía de campo. Ciudad Autónoma de Buenos Aires. Independiente.

Lowe, S., N. Browne, S. Boudpelas \& M. Poorter. 2000. 100 of the world's worst invasive alien species. A selection from the Global Invasive Species Database. Published by the Invasive Species Group (ISSG) a specialist group of the Species Survival Comission (SSC) of the World Conservation Union (IUCN), 12 pp. First published as special liftout in Aliens 12 December 2000. Updated and reprinted version November 2004.

McCallum, M.L. 2007 Amphibian decline or extinction? Current declines dwarf background extinction rate. Journal of Herpetology 41:483-491.

Mettermeier, R.A., P. Robles Gil, M. Hoffman, J. Pilgrim, T. Brooks, C.G. Mittermeier, J. Lamoreux \& Da Fonseca. 2004. Hotspots Revisited: Earth's Biologically Richest and Most Endangered Terrestrial Ecoregions. CEMEX, Mexico City.

Montanelli S.B. \& S. Acosta. 1991. Lista preliminar de la herpetofauna del Parque Nacional Iguazú. Boletín Asociación Herpetológica Argentina 7:9-10.

Myers, N., R.A. Mittermeier, C.G. Mittermeier, G.A.B. da Fonseca \& J. Kent. 2000. Biodiversity hotspots for conservation priorities. Nature 403:853-858.

Oyarzabal, M., J. Clavijo, L. Oakley, F. Biganzoli, P. Tognetti, I. Barberis, H.M. Maturo, R. Aragon, P.I. Campanello, D. Prado, M. Oesterheld \& R.J.C. León. 2018. Unidades de vegetación de Argentina. Ecología Austral 28:40- 43.

Pereira, G., R. Maneyro. 2016. Movement Patterns in a Uruguayan Population of Melanophryniscus montevidensis (Philippi, 1902) (Anura: Bufonidae) Using Photo-identification for individual recognition. South American Journal of Herpetology 11:119-126.

Placci, G. \& M. Di Bitetti. 2006. Situación ambiental en la Ecorregión del Bosque Atlántico del Alto Paraná (Selva Paranaense). Pp 197209. In: A. Brown, U. Martinez Ortiz, M. Acerbi \& J. Corcuera 
(Eds.). La Situación Ambiental Argentina 2005, Fundación Vida Silvestre Argentina, Buenos Aires.

R Core Team 2019. R: A language and environment for statistical computing. R Foundation for Statistical Computing, Vienna, Austria. URL https://www.R-project.org/.

Ribeiro, M.C., J.P. Metzger, A.C. Martensen, F.J. Ponzoni \& M.M. Hirota. 2009. The Brazilian Atlantic Forest: How much is left, and how is the remaining forest distributed? Implications for conservation. Biology Conservation 142:1141-1153.

Rocha, C.D.F., D. Vrcibradic, M.C. Kiefer, M. Almeida-Gomes, V.N.T. Borges-Junior, V.A. Menezes, C.V. Ariani, J.A.L. Pontes, P. Goyannes-Araujo, R.V. Marra, D.M. Guedes, C.C. Siqueira \& M. Van Sluys. 2013. The leaf-litter frog community from Reserva Rio das Pedras, Mangaratiba, Rio de Janeiro State, Southeastern Brazil: species richness, composition and densities. NorthWestern Journal of Zoology 9:151-156.

Rosset, S.D., R.M. Fadel, C.S. Guimarães, P.S. Carvalho, K. Ceron, M. Pedrozo, R. Serejo, V.S. Souza, D. Baldo \& S. Mângia. 2021. A New Burrowing Frog of the Odontophrynus americanus species Group (Anura, Odontophrynidae) from Subtropical Regions of Argentina, Brazil, and Paraguay Ichthyology \& Herpetology 109:228244.

Ryan, M.J., M.M. Fuller, N.J. Scott, J.A. Cook, S. Poe, B. Willink, G. Chaves \& F. Bolaños. 2014. Individualistic population responses of five frog species in two changing tropical environments over time. PLOS One 9:e98351.

Ryan, M.J., N.J. Scott, J.A. Cook, B. Willink, G. Chaves, F. Bolaños, A. García Rodríguez, I.M. Latella \& S.E. Koerners. 2015. Too wet for frogs: changes in a tropical leaf litter community coincide with La Niña. Ecosphere 6:4.

Scheele, B.C., F. Pasmans, L.F. Skerratt, L. Berger, A. Martel, W. Beukema, A.A. Acevedo, P.A. Burrowes, T. Carvalho, A. Catenazzi, I. De la Riva, M.C. Fisher, S.V. Flechas, C.N. Foster, P. Frías-Álvarez, T.W.J. Garner, B. Gratwicke, J.M. Guayasamin, M. Hirschfeld, J.E. Kolby, T.A. Kosch3, E. La Marca, D.B. Lindenmayer, K.R. Lips, A.V. Longo, R. Maneyro, C.A. McDonald, J. Mendelson III, P. Palacios-Rodriguez, G. Parra-Olea, C.L. Richards-Zawacki, M.O. Rödel, S.M. Rovito, C. Soto-Azat, L.F. Toledo, J. Voyles, C. Weldon, S.M. Whitfield, M. Wilkinson, K.R. Zamudio \& S. Canessa. 2019. Amphibian fungal panzootic causes catastrophic and ongoing loss of biodiversity. Science 363:14591463.

Scott Jr., N.J. 2001. Inventario completo de especies. Pp. 71-135. In: Heyer, W.R., M.A. Donnelly, R.W. McDiarmid, L.A.C. Hayek and M.S. Foster (eds.). Medición y monitoreo de la diversidad biológica - Métodos estandarizados para anfibios. Smithsonian Institution Press, Editorial Universitaria de la Patagonia.

Scott Jr., N.J. \& B.D. Woodward. 1994. Surveys at breeding sites. Pp. 118-125. In W.R. Heyer, M.A. Donnelly, R.W. McDiarmid, L.A.C. Hayek and M.S. Foster (eds.). Medición y monitoreo de la diversidad biológica - Métodos estandarizados para anfibios. Smithsonian Institution Press, Editorial Universitaria de la Patagonia.

SIB, 2017. Sistema de Información de Biodversidad. Administración de Parques Nacionales. Download: https://sib.gob.ar/archivos/ ANEXO_I_PGIguazú.pdf

Silva, E.T., O.P. Ribeiro Filho \& R.N. Feio. 2011. Predation of native anurans by invasive bullfrogs in southeastern Brazil: spatial variation and effect of microhabitat use by prey. South American Journal of Herpetology 6:1-10.

Srur, M., F. Gatti, V. Benesovsky, J. Herrera, R. Melzew \& M. Camposano. 2009. Los tipos de vegetación y ambientes del Parque Nacional Iguazú y su distribución en el paisaje. Pp 99118. In: Carpinetti, B., M. Garciarena \& M. Almirón (Eds.). 2009. Parque Nacional Iguazú, Conservación y desarrollo de la Selva Paranaesnse de Argentina. $1^{\mathrm{a}}$ ed. Buenos Aires, Administración de Parques Nacionales.

Stuart, S. 2006. Scinax aromothyella. The IUCN Red List of Threatened Species 2006:e.T61792A12547466. [Downloaded on 26 February 2020].

Toft, C.A. 1985. Resource partitioning in amphibians and reptiles. Copeia 1985:121.

Vaira. M., M. Akmentins, M. Attademo, D. Baldo, D. Barrasso, S. Barrionuevo, N. Basso, B. Blotto, S. Cairo, R. Cajade, J.V. Corbalán, P. Chilote, M. Duré, C. Falcione, D. Ferraro, F.R. Gutiérrez, M.R. Ingaramo, C. Junges, R. Lajmanovich, J.N. Lescano, F. Marangoni, L. Martinazzo, R. Marti,. L. Moreno, G.S. Natale, J.M. Pérez Iglesias, P. Peltzer, L. Quiroga, S. Rosset, E. Sanabria, L. Sánchez, E. Schaefer, C. Úbeda \& V. Zaracho. 2012. 
Categorización del estado de conservación de los anfibios de la República Argentina. Cuadernos de Herpetología 26 (supl. 1):131159.
Wells, K.D. 2007. The ecology and behavior of amphibians. The University of Chicago Press.

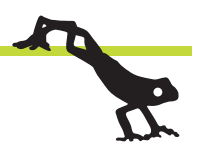

